\title{
Students' Writing Anxiety: How Does It Affect Students' Writing Performance in EFL Context?
}

\author{
${ }^{1 s t}$ Ishanisha Karlina \\ Graduate School of English Education \\ Yogyakarta State University \\ Yogyakarta, Indonesia \\ isnanisha93@gmail.com
}

\author{
${ }^{2 n d}$ Nur Hidayanto Pancoro \\ Graduate School of English Education \\ Yogyakarta State University \\ Yogyakarta, Indonesia \\ nur_hidayanto@uny.ac.id
}

\begin{abstract}
A rapidly growing body of research has been recently focusing on the various aspects of foreign language writing due to the fact that constructing a comprehensive and coherent written text is the most challenging task encountered by foreign language learners. Possessing a good writing ability is dependent to many aspects including the learners' psychological aspects. One of the most influencing aspects is writing anxiety, which has been claimed to influence learner' motivation and attitudes towards writing. In addition, despite the substantial body of research that has investigated how writing anxiety interacts with general language proficiency, there is a general lack of research in establishing the relationship between writing anxiety and writing performance. As a reflection to the these matters, the current paper reviews the literature in relation to the two mentioned variables to explore, identify, and analyze the unique relationships existing between writing performance and writing anxiety in order to shed light on this crucial topic and to provide an up-to-date and well-structured overview of the literature in terms of the extent to which writing anxiety impacts the writing performance based on literature and previously conducted studies. The overview provided by the current paper will contribute significantly in providing an overview of knowledge available for future researches and real-world applications in order to deal with the previously mentioned problems facing EFL learners in terms of writing skill mastery.
\end{abstract}

Keywords—writing anxiety; writing performance; EFL

\section{INTRODUCTION}

Many researchers have put a concern on anxiety as one of the factors that can affect language learning process [1]. The anxiety as the feeling of worried. It makes the association to the autonomic nervous system [2]. It can disturb the concentration and create the feeling of worried about something uncertain which might happen or not. The feeling of uneasiness, apprehension, or worry will make everything hard to do. In the educational setting, learners will feel anxious when they perform activities which need productive skill [3]. Writing, as one of productive skills, is known to be sensitive to learners' anxiety. The writing plays a crucial role in learning English as a foreign language [4]. Every EFL learner must master the writing skill because it is a survival skill which will support him to master another given tasks.
Writing skill is claimed as a requirement for the success in all academic fields and workplaces [5]. The most challenging language skill is writing which is a complex process itself [6]. Both first and foreign language learners tend to face difficulty when trying to write. Moreover, writing is the most difficult skill for the L2 students to master [7]. This difficulty is due to both cognitive and non-cognitive factors, e.g. writing anxiety.

Many studies showed that the L2 students experience writing anxiety [8]. It is caused by language complexity and writing complexity [9]. Writing is not an easy task because it is a set of composing process. It starts from setting goals, building ideas, collecting information, selecting language up to organizing the text. The writing process becomes more difficult and challenging when the language is a foreign or second language. Writing in a foreign language context sometimes makes learners feel more anxious which in turn will lead to negative effect on their writing outcome [10]. Thus anxiety can determine the result of the learning [11]. Hence, there is a need to investigate how writing anxiety can affect learners writing performance.

\section{WRITING ANXIETY}

Writing anxiety as the situation where the learner tends to avoid a situation which needs writing activity [12] It creates writing avoidance behavior and tends to avoid writing evaluation. Following that, Second Language Researchers started to analyze anxiety as a skill-specific construct. For many years, writing anxiety has been considered as one of the individual differences which gives negative effect on the learning outcome. In the same vein, there are several components of anxiety arising while writing in the L2 [13]. The first is confidence in L2 writing which acts as a double construct. Learners' perception of the writing task difficulty and L2 writing performance' self-assessment play an important role to build self confidence in writing. The second component is concern to motivation and attitude toward learning the L2. The learner who feel that learning the L2 is important and display interest in the area tends to cope with low level of stress [13]. The third is effort to learn L2. 
Learners who engage with another L2 activities display a lower level of anxiety.

Anxiety can be divided into three conceptualization, such as Cognitive Anxiety, Somatic Anxiety and Avoidance Behavior [14]. Cognitive anxiety is the reflection of the cognitive aspect of the anxiety such as having negative expectation and fear of others' perception. Somatic anxiety is an anxiety which is indicated by the appearance of the physiological effects, such as tension and nervousness. Avoidance behavior is a behavior aspect which appears because of the anxiety experienced. Some information are known to be related to anxiety factors [15]. There is a cognitive factors that can influence the development of the anxiety. It focuses on the role of a disorted and dysfunctional way of thinking. The way of thinking which is associated with the anxiety are as follows: (1) Excessive predictor of fear, person who feel anxiety often underestimates how much they will feel the anxiety in the time they are facing frightening situation, (2) Self-defeating confidence, it can increase the person's level of the anxiety, (3) Excessive sensitivity to the threats, every situation is considered as a threatening situation, (4) Anxiety Sensitivity, it is a form of anxiety fear, (5) Low level of self-efficacy, people with high level of anxiety cannot control themselves as a result they cannot cope with the stress. If they do not have the ability to cope with it they will feel more anxious when they face new challenge. Conversely, if they can cope with it, they will not be haunted by the anxiety. Therefore, it can be said the anxiety is associated with a host of cognitive, behavioral, and emotional problems. When the problems are pervasive and severe, they may be diagnosed as anxiety disorders. However, most students who have problems and appear or indicate that they are anxious are not disordered and should not be treated as having a psychopathological condition.

\section{WRITING PERFORMANCE}

Many Second or Foreign Language Learning Researches involve three dimensions to measure the L2 proficiency and writing proficiency of the L2 learners [16]. Namely, accuracy, complexity and fluency. If the L2 learners who increase the three aspects on the language learning, they will get great benefit for their writing performance [17].

To produce writing that is linguistically accurate is one of the most notorious hurdles for ESL learners [18]. However, the degree of linguistic accuracy expected of the learners has caused much controversy. If the teacher believes that the goal is to communicate ideas to a native speaker, he or she tolerates students' imperfect writing inasmuch as native speakers almost always understand faulty writings of second language learners. If, on the other hand, the teacher puts emphasis on linguistic accuracy in addition to communicating ideas, he or she regards grammatical correctness as an indispensable component of learners' writing ability. In choosing different standards of performance and an appropriate level of grammatical perfectibility, writing teachers, thus, have to take into account learners' giftedness, specialization, willingness to be corrected, learners' needs and goals, and their level of selfesteem. If it is a bitter fact that it is a tedious task to express thoughts in writing, even in one's native language, teachers should do their best to primarily deal with the affective aspects of writing in ways that provide the most supportive and natural circumstances in which students' psychological and emotional attitudes to writing activities are considered. In this way, teachers most probably would be able to reduce learners' negative attitudes and their effects on learners' writing outcomes to manage the writing process and provide learn.

\section{THE RELATIONSHIP BETWEEN WRITING ANXIETY AND WRITING PERFORMANCE}

As previously mentioned, there is a relationship between writing anxiety and writing performance. The thing that needs to be confirmed is whether the writing anxiety is the cause or the effect of the low result of the writing performance. In general language learning, anxiety has two effects on the language learning process. It motivates learners to learn what will facilitate the language learning process if the learners experience a little bit on anxiety. Conversely, it can keep the learners stay alert. Its negative effects are that it can decrease the learners' result of the language learning outcome. The learners who try to complete activities that requires productive skills tend to face anxiety [19]. Writing is a productive skill which is the most challenging L2 skill to develop [20]. It involves a complex process such as planning, generating and organizing the ideas. The Learners who experience higher level of anxiety tend to avoid writing activities [13]. That is why their writing performance tends to be lower than other learners. Two instruments namely, Writing Quality Task and Writing Quantity Task are used to prove that learners with lower anxiety tend to have a better writing performance [12].

Likewise writing is a productive skill which requires the learners to produce a coherent and cohesive outcomes such as paragraphs, letters, essays, papers, proposals, articles and so on. The learners have to construct words into sentences, develop sentences into paragraphs and organize them into essays so it will be a meaningful text. Besides, to create a coherent and cohesive text the writer should consider the word choice, appropriate grammar, word order and the ideas' organization [21]. The learners who experience anxiety tend to perform low result due to the acquisition deficiency [22]. Their deficiency makes them more anxious. In the same vein, the learners' poor performance is caused by the disability of the learners' cognitive-linguistic and it changes into anxiety [23].

The effect of writing anxiety towards writing performance seems to be specified into several variables such as individual differences, affective and psychological aspect. It is necessary to consider learners' perception, beliefs and differences in relating the writing anxiety and writing performance [10]. Freshman learners are more anxious than the senior learners due to the fact that senior students get more experience of numerous writing tasks during the language writing learning process [10]. It can be concluded that anxiety can be decreased 
by the age. The older the learners the more experience they get.

Gender plays a vital role in the language learning process. There is also indicator of the effect of genders' writing anxiety towards their writing performance. Male learners experience greater amount of anxiety than the female learners related to their writing performance [24]. Females can endure the stress better than males do [25]. Additionally, female learners have better attitude than males do in language writing process [26]. The females can enjoy the writing process better than males do [27]. There are several differences between male and female in relation to enjoying the writing process, having prejudice toward writing process and facing the anxiety during the writing process [28]. To sum up, the learners' writing anxiety and writing performance affect, and be affected by how they feel about themselves. Thus highly anxious learners produce less quality writing outcome or performance, avoid writing activities given, and show adjournment in doing the writing activities. Learners make the learners do not have higher expectation of their writing scores. They lose the willingness to engage in every writing activity.

\section{STRATEGY TO COPE WITH WRITING ANXIETY}

Writing anxiety is one of the problems faced by the ESL or EFL learners which can inhibit the writing process. As previously mentioned, that the writing anxiety can give negative effect to the writing performance, thus, it is important to know how to cope with the writing anxiety. There are numerous ways to reduce the learners' writing anxiety so that they can get the better writing results. It is urge to know the importance of reducing the learners' writing anxiety [29]. First of all, anxiety contributes negatively in the writers' success in writing. Though learners show a higher level of the writing anxiety which give negative impact to the writing performance. Secondly, the learners need to develop their writing skill to motivate them in their study. Thirdly, the instructor or teacher must realizes that their learners feel anxious when they are asked to compose a text therefore they need to modify the teaching instruction to reduce the anxiety.

There are several ways to reduce the learners' writing anxiety. Namely, (1) asking to write more, (2) listening to the anxious learner' complaint, (3) sharing the writing experience of the teacher, (4) finding the learner's problem in the correct pattern, (6) conferencing during the composing stage, (7) making a collaboration with the learner for deciding evaluation criteria, (8) making peer evaluation, (9) considering gender differences, (10) monitoring the attitude [30]. The reduction of the writing anxiety can be done by the learners themselves [31]. There are several strategies that can be done by the learner to reduce their writing anxiety, e.g. (1) learners must get their confidence on their own writing, (2) marking a specific point for every stage, (3) having a break when feel unwell, (4) following the writing process step by step, (5) making an outline before starting to write, (6) write several drafts before writing, (7) thinking positively towards the anxiety, (8) learning the writing strategies, (9) accepting every mistake made and making it as learning process. In addition the learners can use two ways in reducing the writing anxiety they face such as behavior strategy and expert review and feedback strategy [32]. The conclusion is most of the studies claimed that the reduction of the writing anxiety mostly done through teacher's perspective and experiences [32]. To sum up, several criteria are built to know the success of writing such as flowing the ideas smoothly, gaining more confidence, having an enjoyment in the L2 writing process, expressing themselves into good writing [33].

\section{CONCLUSION}

Writing anxiety is mostly correlated with writing performance in the foreign language context for several years, which cause serious obstacles for the learners to master the writing skill. It is one of the psychological aspects that can influence the writing performance of the learner. The complexity in writing triggers the feeling of uneasiness of the learners. This aspect causes the poor performance of the learner due to the fact that it can interfere with the language writing process. It affects the willingness of the learner to take opportunity to write. Higher anxious learners tend to perform worse writing outcome rather than lower anxious learners. Therefore, the anxiety is considered as one of the factors that mostly affects the writing performance of the learners. As a reflection to this matter, it is highly requested for future studies to focus on the relationship between all the factors affecting the anxiety and their direct influence on the writing performance. In addition, more studies are needed in terms of the way how to improve the writing performances of the learners.

\section{References}

[1] G. Kurt, and D. Atay, "The Effects of Peer Feedback on the Writing Anxiety of Prospective Turkish Teachers of Efl,’ J. Theory Pract. Educ., 3, p. 12-23, 2008

[2] E. K. Horwitz, M. B. Horwitz, J. Copw, "Foreign Language Classroom Anxiety," The Modern Language Journal, 70, p.125-132, 1986

[3] L. J. Zhang, "Exploring variability in language anxiety: Two groups of PRC students learning ESL in Singapore," RELC Journal, 32(1), p. 73-91, 2001

[4] M. A. M. Kassem, "Developing Business Writing Skills and Reducing Writing Anxiety of EFL Learners Through Wikis," Canadian Center of Science and Education, p. 151-163, 2017.

[5] W. Condon, and D. Kelly-Riley "Assessing and Teaching What We Value: The Relationship Between CollegeLevel Writing and Critical Thinking Abilities," Assessing Writing, 9(1), p. 56-75, 2004,

[6] I. Umar, and M. Rathakrishnan, "The effects of online teachers' social role and learning style on students' essay writing performance and critical thinking in a wiki 
environment," Procedia Social and Behavioral Sciences, 46, p. 5730-5735, 2012.

[7] J. Richards, Methodology in Language Teaching, An Anthology of Current Practice. United States of America: Cambridge University Press, 2002.

[8] A. Tezba, and A. Ankara, Likert-Type Scale Development Guides (Second Printing): Turkish Psychological Association Publications., 1977.

[9] R. Bruning, and C. Horn, "Developing Motivation To Write. Educational Psychologist,” 35 (1), p. 25-37, 2000.

[10] E. Ekmekci, 'Exploring Turkish EFL Students' Writing Anxiety," The Reading Matrix: An International Online Journal 18, 2018.

[11] E. K. Horwitz, "It ain't over 'til it's over: On foreign language anxiety, first language deficits, and the confounding of variables," Modern Language Journal, 84, p.256-259, 2000.

[12] B. A. Hassan, "The relationship of writing apprehension and self-esteem to the writing quality and quantity of EFL University students," Mansoura Faculty of Education Journal, 2001.

[13] Y. S. Cheng, "Factors Associated with Foreign Language Writing Anxiety," Foreign Language Annals 35, p. 647656, 2002.

[14] Y. S. Cheng, "A measure of second language writing anxiety: Scale development and preliminary validation. Journal of Second Language Writing, 13, p. 313-15, 2004.

[15] Nevid, J.S, et all,. Psikologi Abnormal jilid 1.Jakarta: Erlangga. 2003

[16] R. Ellis, and G. Barkhuizen, (2005). Analyzing learner language. Oxford: Oxford University Press, 2005.

[17] P, Skehan, A framework for the implementation of taskbased instruction. Applied Linguistics, 17(3), p.38-62, 1996.

[18] E. Hinkel, Second language writers' texts: linguistic and rhetorical features. Mahwah, NJ: Lawrence Erlbaum, 2002.

[19] L. J. Zhang, "Exploring variability in language anxiety: Two groups of PRC students learning ESL in Singapore. RELC Journal, 32(1), p.73-91, 2001.

[20] M. Saedi, and M. Farnia, "Iranian EFL Learners' Perceived Writing Anxiety and the Complexity, Accurac1y, and Fluency of their Task-based Writing: Are they Correlated?," Journal of Applied Linguistics and Language Research, 4, p. 68-78, 2017.

[21] Attamim, O. Z, The implementation of cooperative learning to improve the students' proficiency in writing paragraphs. Ponorogo: Muhammadiyah University of Ponorogo. 2007.

[22] M. Naveh-Benjamin, "A comparison of training programs intended for different types of testanxious students: Further support for an information-processing model," Journal of Educational Psychology, 83, p.134-139, 1991.

[23] R. Sparks, L. Ganschow, and J. Javorsky, "Déjà vu all over again: a response to Saito, Horwitz, and Garza," Modern Language Journal, 84, p.251-255, 2000.

[24] N. Jebreil, A. Akbar , H. Gowhary, "Investigating the Effect of Anxiety of Male and Female Iranian EFL Learners on their Writing Performance," Procedia - Social and Behavioral Sciences, 185, p.190-196, 2015.

[25] C. D. Spielberger, Manual for the state-trait anxiety inventory. Palo Alto, CA: Consulting Psychologists Press, 1983.

[26] K. Iseri, "Evaluation of The Writing Disposition of Elementary School Sixth Grade Students," New Educ. Rev., 22(3) p.295-308, 2010.

[27] Clark C, Dugdale G, Young people's writing: Attitudes, behavior and the role of technology. London: National Literacy Trust. 2009.

[28] K. Z. Zorbaz, Elementary School Students' Writing Written Communication skills Relationship Between Anxiety and stiffness. Ankara: Institute of Educational Sciences, Gazi University, 2010.

[29] Stapa, S. The process approach to ESL writing.Bangi, Selangor: Faculty of Language Stuides, UniversitiKebangsaan Malaysia, Malaysia. 1998.

[30] L. L. Reeves, "Minimizing writing apprehension in the learner-centered classroom," English Journal, 86, p.38-45, 1997.

[31] Clark, D. Explorations into writing anxiety: Helping students overcome their fears and focus on learning. Paper presented at the ISSOTL Conference, Canada. 2005.

[32] Huwari, IF, Yasser Al-Shboul, "Student's Strategies to Reduce Writing Apprehension (A Case Study on Zarqa University)" Mediterranean Journal of Social Sciences MCSER Publishing, Rome-Italy, Vol 7 No 3 S1 May 2016

[33] H. Baştürkmen, and M. Lewis," Learner perspectives of success in an EAP writing course. Assessing Writing, 8 (1), p. 31-46, 2002 